\title{
Cell population, viability, and some key immunomodulatory molecules in different milk somatic cell samples in dairy cows
}

\author{
Amandine Baumert, Rupert M. Bruckmaier and Olga Wellnitz* \\ Veterinary Physiology, Vetsuisse Faculty, University of Bern, Bern, Switzerland \\ Received 4 August 2008; accepted for publication 9 March 2009; first published online 18 May 2009
}

\begin{abstract}
Immune cells in the milk are most important in combating pathogens that invade the mammary gland. This study investigated the immune competence and viability of somatic milk cells that are already resident in milk and udders free of infection. Cells were studied in freshly removed milk to simulate conditions in the udder. Effects of incubation, cell preparation, and immunological stimulation with $0.5 \mu \mathrm{g} / \mathrm{ml}$ lipopolysaccharide (LPS) from Escherichia coli were analysed. Viability and differential counts of milk cells between high and low somatic cell count (SCC) quarters, and cisternal and alveolar milk with and without LPS stimulation were compared. Incubation and preparation of cells caused a cell loss which further increased with time independently of SCC and milk fraction. The viability of these cells was stable until $3 \mathrm{~h}$ post incubation and decreased until $6 \mathrm{~h}$. Cell populations differed between both investigations, but did not change during the course of the experiment. mRNA expression of immune and apoptosis factors of the cells, measured by qPCR, did not change substantially: mRNA expression of caspase 3, Toll like receptor 4, and GM-CSF did not change, whereas the expression of the death receptor Fas/APO-1 (CD95), lactoferrin and lysozyme was decreased at $6 \mathrm{~h}$. Cyclooxygenase-2 and TNF- $\alpha$ mRNA expression were decreased after $6 \mathrm{~h}$ of LPS treatment. In comparison with other studies in vivo or in vitro (in cell culture), in this study where cells are studied ex vivo (removed from the udder but kept in their natural environment, the milk) resident milk cells seem to be more vulnerable, less viable, less able to respond to stimulation, and thus less immune competent compared with cells that have freshly migrated from blood into milk after pathogen stimulation. The cell viability and differential cell count differed between high- and low-SCC milk and between cisternal and alveolar milk depending on the individual cow. In conclusion, the results support the view that for a most effective defence against invading pathogens the mammary gland is reliant on the recruitment of fresh immune cells from the blood.
\end{abstract}

Keywords: Immunity, mammary, milk fractions.

Somatic milk cells [polymorphonuclear neutrophils (PMN), macrophages $(M \phi)$, lymphocytes $(\mathrm{L})$, and some epithelial cells] are crucial for an effective immune defence in the mammary gland. 'Resident' cells which are already in the milk without a preceding immune stimulation are the first cells that come into contact with invading pathogens. Shortly after pathogens are recognized, additional leucocytes are recruited into the milk through the blood-milk barrier and thus somatic cell count (SCC) is increased. This is initiated by inflammatory mediators. Therefore, SCC is used worldwide as an indirect indicator to diagnose intramammary infections and to control bacterial contamination of the udder and milk (Brolund, 1985; Harmon, 1994).

*For correspondence; e-mail: olga.wellnitz@physio.unibe.ch
In healthy cows, macrophages are the predominant cell population particularly in the cisternal milk fraction which is close to the entrance port of the pathogenic agents (Sarikaya et al. 2006). They are able to actively recognize and engulf pathogens, to release chemotactic and inflammatory mediators, and to initiate the inflammatory response (Rainard \& Riollet, 2006). PMN are the predominant cells recruited in large amounts from the blood into the milk during the acute phase of inflammation to fight the causative organism (Harmon \& Heald, 1982; Kehrli \& Schuster, 1994; Sordillo \& Streicher, 2002; Mehrzad et al. 2004). The active stage of immune defence requires viable and immune competent somatic cells for a rapid and efficient elimination of the pathogen. After diapedesis into the mammary gland and participation in the immune response the cells die via apoptosis or necrosis 
pathways (Sládek \& Ryšánek, 1999, 2000) and their remains are removed by phagocytosis. Apoptosis is the result of interactions between death modulators and death receptors (e.g.: Fas/APO-1 (CD95) (Menaker \& Jones, 2003) and Caspases [e.g. caspase3 (Casp3); Robertson et al. 2000].

The immune response is initiated by cell wall components of invading pathogens such as lipopolysaccharide (LPS) (Burvenich et al. 1994; Boudjellab et al. 1998; Schmitz et al. 2004). Therefore, LPS is often used in experiments in vivo (Bannerman et al. 2004; Didier \& Bruckmaier, 2004; Mehrzad et al. 2001a) or in vitro (Boudjellab et al. 1998; Wellnitz \& Kerr, 2004) to stimulate somatic cells and to mimic a bacterial infection. LPS is recognized by the toll like receptor-4 (TLR4) (Takeuchi et al. 1999). The different mechanisms of the immune response are regulated by immunomodulators (Rainard \& Riollet, 2006) such as cytokines e.g. tumour necrosis factor $\alpha(\mathrm{TNF}-\alpha)$ or interleukin 8 (IL-8), antibacterial proteins e.g. lactoferrin (Lf), and lysozyme (Lz), lipid mediators e.g. cyclooxygenase-2 (COX-2), or other factors e.g. granulocyte macrophage colony stimulating factor (GMCSF). Their expression is unregulated in mammary tissue and milk cells during an immune response (Pfaffl et al. 2003).

The differential count of leucocytes can be influenced by milk fraction and SCC (Sarikaya et al. 2006). In addition, the mRNA expression of inflammatory factors is lower in cells of low-SCC milk. High SCC levels $>100 \times$ $10^{3} \mathrm{cell} \mathrm{s} / \mathrm{ml}$ are highly correlated with mastitis (Kehrli \& Shuster, 1994). In addition, elevated SCC can reduce the susceptibility to mastitis (Suriyasathaporn et al. 2000). Therefore it is possible that the immunological activity of resident cells is different in high- and low-SCC milk. The milk fraction can also have an influence on the SCC and the cell viability. Sarikaya et al. (2005) found a higher SCC and cell viability in the foremilk fraction compared with the alveolar fraction.

This study was performed to investigate the importance, for the immunity of the mammary gland, of cells already resident in milk before an infection occurs. The ex-vivo condition of the study allowed us to investigate these cells after removal from the udder in their natural environment, the milk, without the influence of new cells recruited from the blood or contribution of the mammary tissue. The viability, cell differentiation and mRNA expression of several immunomodulating factors of these cells were tested. A special focus was the comparison of viability and cell differentiation between quarters with high and low SCC and of foremilk and alveolar milk fractions.

\section{Materials and Methods}

\section{Experiment 1}

Ten lactating dairy cows were chosen at random (5 Red Holstein, 5 Holstein). Cows were in months 2 to 9 of their 2nd to 7 th lactation with a SCC of $140 \pm 57 \times 10^{3}$ cells $/ \mathrm{ml}$. Whole milk was harvested by machine milking in the morning. Five-hundred $\mathrm{ml}$ was filtrated (pore size $100 \mu \mathrm{m}$ ) and incubated at $37^{\circ} \mathrm{C}$. After $0,1.5,3,4.5$ and $6 \mathrm{~h}$ of incubation, SCC was measured with an automated milk cell counter (DCC; DeLaval, Tumba, Sweden) to evaluate changes of SCC during incubation.

Cell isolation was performed according to Sarikaya et al. (2004) with modifications as follows: after each incubation period, $30 \mathrm{ml}$ of the milk samples were diluted $1: 1$ with cold $\left(4{ }^{\circ} \mathrm{C}\right)$ sterile phosphate-buffered saline (PBS; $\mathrm{pH}=7 \cdot 4)$ and centrifuged at $1000 \mathrm{~g}$ at $4{ }^{\circ} \mathrm{C}$ for $15 \mathrm{~min}$. The fat layer and supernatant were removed and the cell pellet resuspended and centrifuged twice in $30 \mathrm{ml}$ PBS (400 $g$ and $300 \mathrm{~g}$ at $4{ }^{\circ} \mathrm{C}$ for $\left.10 \mathrm{~min}\right)$. The final pellet was resuspended in cold PBS (depending on the original total cell concentration in $50 \mu \mathrm{l}$ to $1 \mathrm{ml}$ to obtain an optimal cell concentration for differentiation). Twenty-five $\mu l$ of the cell suspension was used for determination of cell count and viability in a Neubauer's counting chamber (Brand, Wertheim, Germany) with direct light microscopy using a Trypan blue staining (1:1 dilution). Viable cells appeared shining white under the microscope while dead cells appeared blue.

\section{Experiment 2}

Eleven lactating dairy cows (4 Red Holstein, 4 Holstein, 3 Brown Swiss) were selected based on milk SCC $<150 \times 10^{3}$ cells $/ \mathrm{ml}\left(60 \pm 10 \times 10^{3}\right.$ cells $\left./ \mathrm{ml}\right)$ determined by the DCC. The cows were in months 2 to 8 of their 1 st to 6 th lactation. They were clinically healthy and had no signs of inflamed udders such as redness, swelling or heat. Whole udder milk was collected during morning machine milking and kept at $4{ }^{\circ} \mathrm{C}$ for approximately $1 \mathrm{~h}$ until further preparation. The milk was filtrated (pore size, $100 \mu \mathrm{m}$ ) and separated into aliquots of $500 \mathrm{ml}$. One sample from each cow was treated with $0.5 \mu \mathrm{g} / \mathrm{ml}$ LPS from Escherichia coli (O111:B4; SIGMA, Buchs, Switzerland) another sample from each cow was not treated (controls). All samples were incubated at $37^{\circ} \mathrm{C}$ for 1,3 or $6 \mathrm{~h}$. Then samples were centrifuged and the cells washed as for Experiment 1. Final pellets were resuspended in $2 \mathrm{ml}$ of cold PBS.

Cell count and cell viability was determined microscopically (see Experiment 1). Cell differentiation was performed using a panoptic staining method according to Pappenheim modified for milk cells (Sarikaya et al. 2004).

After the last step, remaining milk cells from 6 of these cows (SCC $=51 \pm 7 \times 10^{3}$ cells $/ \mathrm{ml}$ ) were centrifuged at $300 \mathrm{~g}$ at $4{ }^{\circ} \mathrm{C}$ for $5 \mathrm{~min}$ and pellets stored at $-80{ }^{\circ} \mathrm{C}$ until RNA extraction. Total RNA was extracted using RNeasy Mini Kit (Quiagen, Hilden, Germany) according to the manufacturer's instructions. Final RNA concentration was quantified by spectrophotometry (Biophotometer, Vaudaux-Eppendorf, Basel, Switzerland) from the optical density at $260 \mathrm{~nm}$. One microgram of RNA was reverse 
Table 1. Sequence of PCR Primers forward (for) and reverse (rev), PCR product length (bp), accession number, Annealing temperature $\left({ }^{\circ} \mathrm{C}\right)$, and reference of primers. The primers without a given reference were designed in our laboratory by using the sequence found with the accession numbers. The product of all primers gave good efficiency, and they were suitable for qPCR in this study

\begin{tabular}{|c|c|c|c|c|c|c|}
\hline Primer & & Sequence $\left(5^{\prime} \rightarrow 3^{\prime}\right)$ & Length & Accession no. & $\begin{array}{l}\text { Annealing } \\
\text { temperature }\end{array}$ & Source \\
\hline \multirow[t]{2}{*}{ TNF- $\alpha$} & for & CCA CGT TGT AGC CGA CAT C & 155 & NM_173966 & 60 & \\
\hline & rev & CCC TGA AGA GGA CCT GTG AG & & & & \\
\hline \multirow[t]{2}{*}{ Lf } & for & GGC CTT TGC CTT GGA ATG TAT C & 338 & DQ522305 & 60 & \\
\hline & rev & ATT TAG CCA CAG СТC ССТ GGA G & & & & \\
\hline \multirow[t]{2}{*}{ IL-8 } & for & ATG ACT TCC AAG СTG GCT GTT G & 150 & EU276073 & 60 & \\
\hline & rev & TTG ATA AAT TTG GGG TGG AAA G & & & & \\
\hline \multirow[t]{2}{*}{ COX-2 } & for & TCC TGA AAC CCA CTC CCA ACA & 242 & AF031698 & 62 & Takagi et al. 2007 \\
\hline & rev & TGG GCA GTC ATC AGG CAC AG & & & & \\
\hline \multirow[t]{2}{*}{ GM-CSF } & for & TTC TCC GCA CCT ACT CGC & 195 & U22385 & 62 & \\
\hline & rev & GTT CTT GTA CAG CTT CAG GCG & & & & \\
\hline \multirow[t]{2}{*}{ Lz } & for & GAG ACC AAA GCA CTG ATT ATG & 195 & U25810 & 62 & \\
\hline & rev & TCC ATG CCA CCC ATG CTC TAA & & & & \\
\hline \multirow[t]{2}{*}{ TLR4 } & for & TAT GAA CCA CTC CAC TCG CTC & 207 & DQ839566 & 62 & \\
\hline & rev & CAT CAT TTG CTC AGC TCC CAC & & & & \\
\hline \multirow[t]{2}{*}{ Casp3 } & for & GAC CAT AGC AAA AGG AGC A & 211 & NM_001077840 & 55 & Yuan et al. 2004 \\
\hline & rev & CAC TGT CTG TCT CAA TAC CAC & & & & \\
\hline \multirow[t]{2}{*}{ Fas } & for & ATG GGC TAG AAG TGG AAC AAA C & 206 & NM_174662 & 60 & Taniguchi et al. 2002 \\
\hline & rev & CAG GAG GGC CCA TAA ACT GT TTG C & & & & \\
\hline \multirow[t]{2}{*}{ GAPDH } & for & GTC TTC ACT ACC ATG GAG AAG G & 197 & NM_001034034 & 60 & \\
\hline & rev & TCA TGG ATG ACC TTG GCC AG & & & & \\
\hline \multirow[t]{2}{*}{ UBQ } & for & AGA TCC AGG ATA AGG AAG GCA T & 198 & NM_174133 & 62 & \\
\hline & rev & GCT CCA CCT CCA GGG TGA T & & & & \\
\hline
\end{tabular}

transcribed with $200 \mathrm{U}$ Moleney Murine Lekaemia Virus Reverse Transcriptase RNase $\mathrm{H}$ minus, Point Mutant (MMLV-RT, Promega, Madison WI, USA) using 100 pmol random hexamer primers (Invitrogen, Leek, The Netherlands).

Quantitative RT-PCR analysis was carried out on a Rotor Gene 6000 (Corbett Research, Sydney, Australia) using the Sensimix DNA Kit (Quantace, Biolabo, Châtel $S^{t}$ Denis, Switzerland). Primers for the housekeeping [GAPDH, ubiquitin (UBQ)] and target genes (TNF- $\alpha$, IL-8, Lf, Lz, GM-CSF, COX-2, TLR4, Casp3, and Fas) were synthesized commercially (Microsynth, Balgach, Switzerland) using previously published or newly designed primer sequences (Table 1). The following 3-step programme was used: $10 \mathrm{~min}$ at $95{ }^{\circ} \mathrm{C}, 40$ cycles of $95^{\circ} \mathrm{C}$ for $15 \mathrm{~s}$, primer specific annealing temperature for $30 \mathrm{~s}$, and $20 \mathrm{~s} 72{ }^{\circ} \mathrm{C}$, ending with a melting curve programme $\left(60-99{ }^{\circ} \mathrm{C}\right.$, heating rate of $0.1{ }^{\circ} \mathrm{C} / \mathrm{s}$, continuous measurement). Take-off values (second derivative maximum) were achieved by Rotor Gene software version 1.7.40. Target gene expressions were normalized to housekeeping genes.

\section{Experiment 3}

Milk from 12 quarters of 6 randomly chosen dairy cows (3 Red Holstein, 1 Holstein, 2 Brown Swiss) was used. The cows were in months 3 to 10 of their 5 th to 7 th lactation and were clinically healthy. Six quarters with higher SCC (HQ) $\left(253 \pm 169 \times 10^{3}\right.$ cells $\left./ \mathrm{ml}\right)$ and six quarters with lower
SCC (LQ) $\left(17 \pm 11 \times 10^{3}\right.$ cells/ml) were used. The milk was taken during morning milking in two fractions: foremilk (FM) (defined as $<1.5$ min after teat cup attachment) and alveolar milk (AM) (>1.5 min after teat cup attachment) using a quarter milking device for separate quarter milk collection (Sarikaya et al. 2005). To obtain a FM fraction free of alveolar milk, milking was performed without any udder preparation to avoid milk ejection (Bruckmaier \& Blum, 1996). Milk was filtrated (pore size, $100 \mu \mathrm{m}$ ) and incubated at $37^{\circ} \mathrm{C}$ in $50-\mathrm{ml}$ aliquots with or without $0.5 \mu \mathrm{l} / \mathrm{ml}$ LPS from Esch. coli (O111:B4; SIGMA, Buchs, Switzerland) for $0,0.5,1,1.5$ and $2 \mathrm{~h}$. Thereafter, samples were centrifuged and pellets were washed as for Experiment 1. Final cell pellets were resuspended in cold PBS (depending on the original total cell concentration between $100 \mu \mathrm{l}$ and $1.5 \mathrm{ml}$ ). Cell count, cell viability and differential cell count was determined (see Experiments 1 and 2).

\section{Statistical analysis}

Results are presented as means \pm SEM. SCC is presented in percentages wherein SCC at time $0 \mathrm{~h}$ is $100 \%$. Differences in cell count, cell viability, cell differentiation and mRNA expression between control samples and LPS-treated samples, as well as between FM and AM or between different incubation times were tested for significance by paired $t$ test using Sigma Plot 10.0 (Systat Software Inc., San Jose CA, USA). $P<0 \cdot 05$ was considered as significant. 


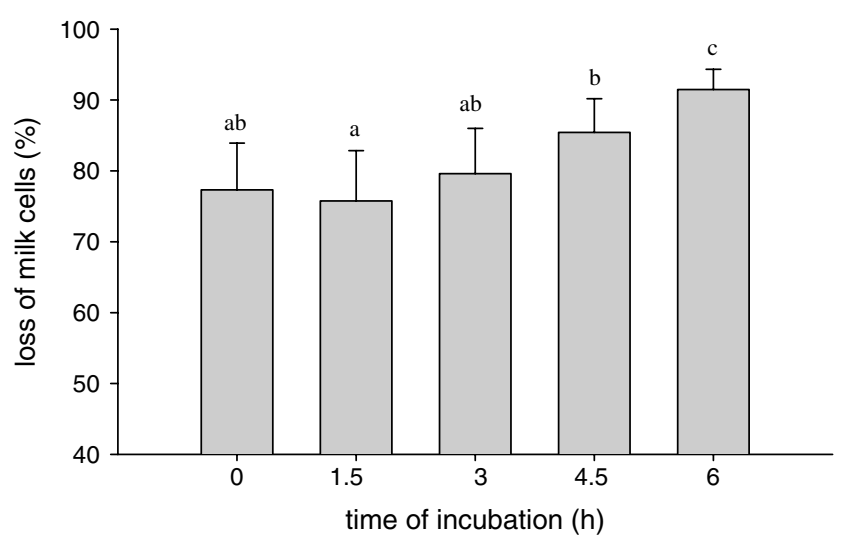

Fig. 1. Decrease of milk cell count (\%) by centrifugation at 0 , $1 \cdot 5,3,4 \cdot 5$, and $6 \mathrm{~h}$ post incubation. Values are means with SEM for $n=10{ }^{a-c}$ : Means without common letters differ significantly $(P<0 \cdot 05)$. The cell loss by centrifugation increased with incubation time.

\section{Results}

\section{Experiment 1}

SCC measured by the DCC before centrifugation of the milk was largely higher than the microscopic cell count after centrifugation calculated to the total cell count of $30 \mathrm{ml}$ milk. The proportion of cell loss (in \%) over the time and by cell isolation increased significantly (Fig. 1). Viability of the somatic cells at $0 \mathrm{~h}$ was $75 \cdot 3 \pm 5 \cdot 6 \%$ and a significant decrease to $65 \cdot 4 \pm 5 \cdot 3 \%$ between $0 \mathrm{~h}$ and $6 \mathrm{~h}$ was observed.

\section{Experiment 2}

Mean cell counts (Fig. 2) derived from control and LPStreated milk decreased from 0 to $1 \mathrm{~h}$, remained stable from 1 to $3 \mathrm{~h}$, and decreased from 3 to $6 \mathrm{~h}$. Compared with controls, LPS-treated samples contained a lower number of cells at 1,3 and $6 \mathrm{~h}$. Cell viability (Fig. 2) at $0 \mathrm{~h}$ was $74 \cdot 7 \pm 3 \cdot 5 \%$ and decreased between 3 and $6 \mathrm{~h}$ in control samples. In LPS-treated samples cell viability decreased between 3 and $6 \mathrm{~h}$.

At time $0 \mathrm{~h}$, the cell population contained $71 \pm 3.9 \%$ PMN, $23 \cdot 5 \pm 4 \cdot 3 \% M \phi$, and $5 \pm 0 \cdot 8 \%$ L. Mean PMN concentration decreased between 0 and $1 \mathrm{~h}$ in control and in LPS-treated samples (Fig. 3). Percentages of $L$ and $M \phi$ did not change significantly with time.

mRNA expression (Table 2) of Casp3, TLR4, and GM-CSF did not change within incubation time. Fas, TNF$\alpha$, IL-8, and Lf mRNA expression was decreased after $6 \mathrm{~h}$. COX-2 expression was decreased in LPS-treated samples at $6 \mathrm{~h}$. Lz expression was decreased at 3 and $6 \mathrm{~h}$.

\section{Experiment 3}

At $0 \mathrm{~h}$ the number of cells in the 50-ml milk samples after centrifugation was $142 \pm 40 \times 10^{3}$ in LQ_FM, $136 \pm 38 \times 10^{3}$ in LQ_AM, $5016 \pm 1067 \times 10^{3}$ in HQ_FM, and $2587 \pm$ $1071 \times 10^{3}$ in HQ_AM. In LQ milk no significant difference between FM and AM within cow was detected. In $\mathrm{HQ}$ milk within cow there was a decrease of the number of cells between FM and AM in four, an increase in one, and no variation in one sample. In each group at each time point the decrease of the number of cells in foremilk was numerically, but not significantly, larger than in alveolar milk (Fig. 4). There was no significant difference between control and LPS-treated samples.

At $0 \mathrm{~h}$ the proportion of viable cells ranged in LQ_FM from 23 to $61 \%$, in LQ_AM from 28 to $60 \%$, in HQ_FM from 22 to $82 \%$ and in HQ_AM from 15 to $70 \%$. In LQ milk the viability in AM was lower in three, elevated in two, and the same in one quarter compared with FM. In $\mathrm{HQ}$ milk the viability of cells in AM was lower in four, elevated in one and the same in one quarter compared with FM. No significant change of the viability was observed within the $2 \mathrm{~h}$ of the experiment. The distribution of cell populations is shown in Table 3 and did not change during the experiment.

\section{Discussion}

In this ex-vivo model, cells were studied in their natural environment, the milk, compared with in-vitro studies where the cells were cultured in media. The design offers the possibility of analysing the behaviour of resident somatic cells without interaction with mammary tissue or newly migrated leucocytes. To study the immune capacity of mammary glands and milk cells, several studies have been performed in vivo with LPS by intramammary challenges (Mehrzad et al. 2001a; Didier \& Bruckmaier, 2004; Schmitz et al. 2004) or in vitro (Boudjellab et al. 1998; Prgomet et al. 2005). In vivo, besides resident milk cells mammary epithelial cells of the tissue as well as newly infiltrating immune cells can react. For this reason, with experiments in vivo it is difficult to isolate the response to LPS stimulation of the resident somatic cells, which are already in the milk, from other cells. Milk cells were studied in vitro in culture media, which provide an optimal environment; however, this does not correspond to the conditions of somatic cells in vivo. Therefore in the present study the ex-vivo model was used to study the competence of the somatic milk cells to immunologically respond in their natural environment, i.e. milk, without any addition of substitutes or interaction with other cells.

The first experiment was performed to investigate the stability of the cells in the model. The selection criterion of cows was the clinical status (health) of the cow and the udder, but not the SCC or the breed. A lower cell number in the microscopic count (after centrifugation) showed that, obviously, the cell preparation is responsible for the destruction of the cells. The centrifugation forces may have a stronger destructive influence on the milk cells, which 

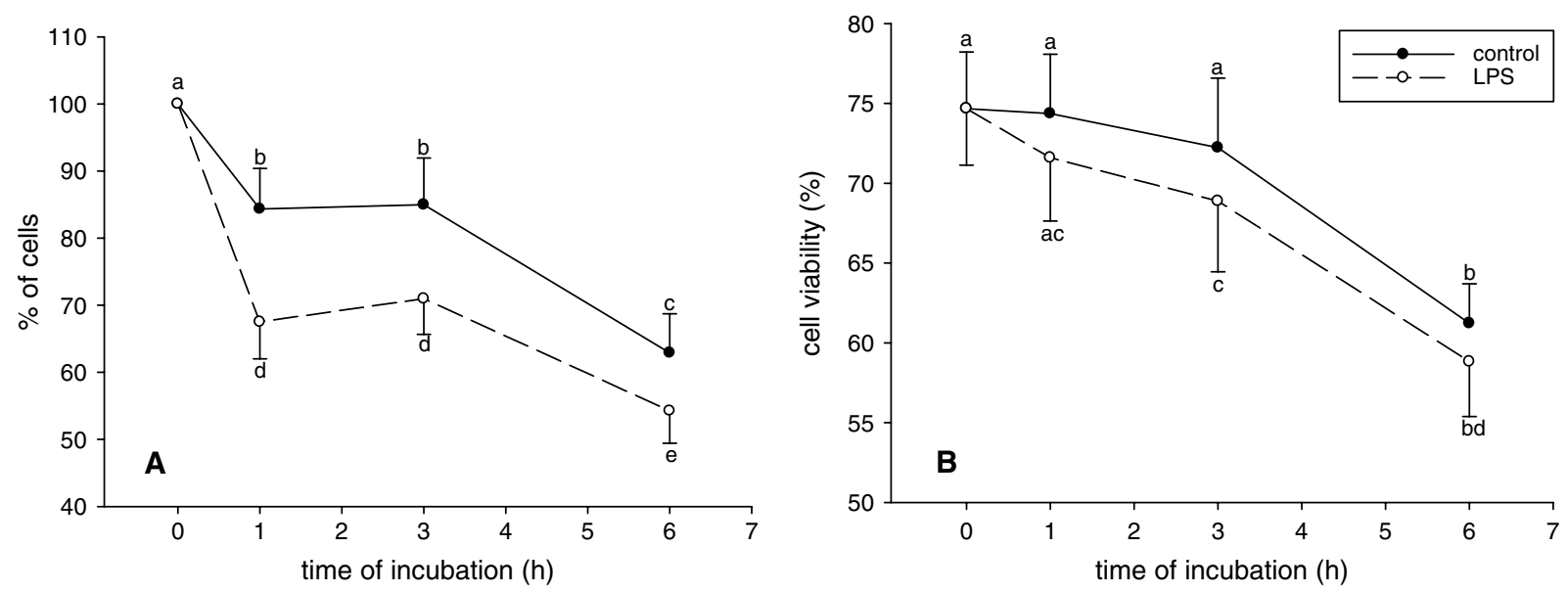

Fig. 2. Milk cell count $(A)$ and cell viability $(B)$ of control $(\bullet)$ and LPS-treated samples $(\bigcirc)$ at $0,1,3$ and 6 h. Values are means with SEM for $n=11{ }^{\text {a-d }}$ : means without common letters differ significantly $(P<0 \cdot 05)$.
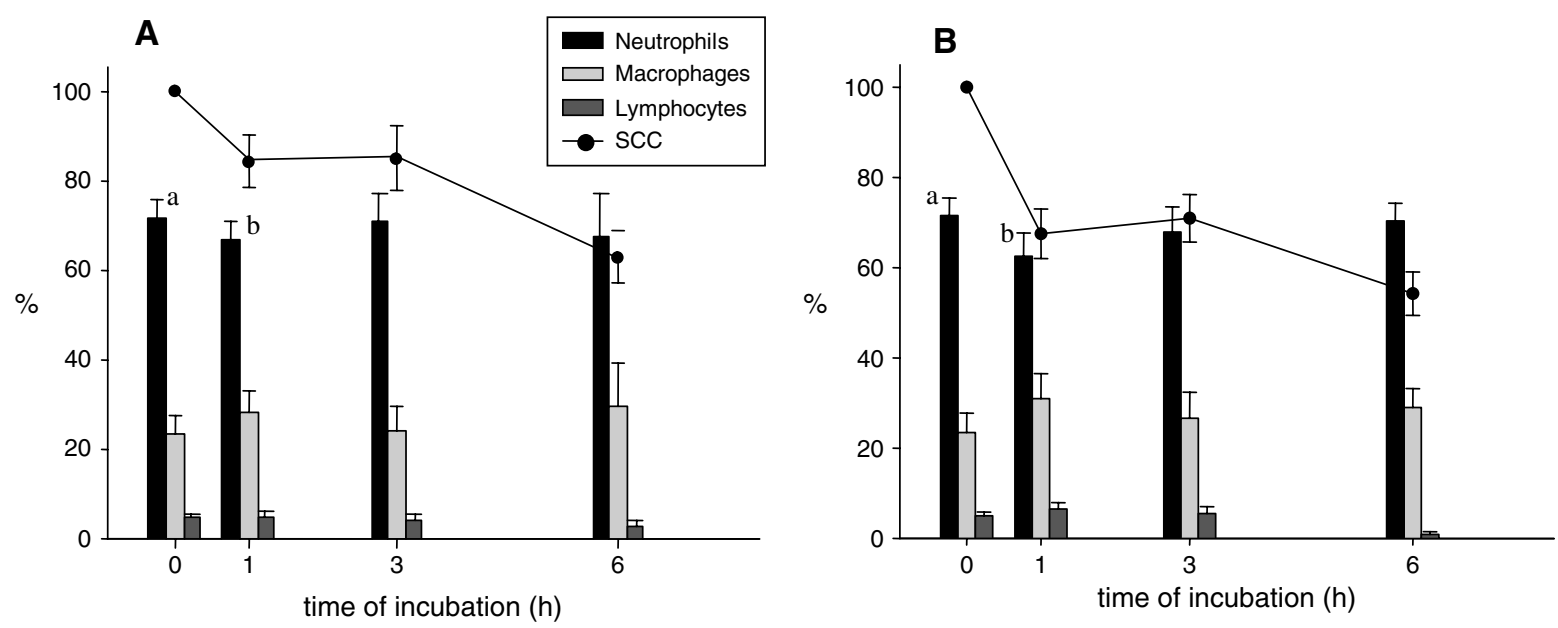

Fig. 3. Decrease of milk cell count in relation to time (line) and cell distribution (bars) at $0,1,3$ and $6 \mathrm{~h}$ : Neutrophils (black), Macrophages (grey), and Lymphocytes (dark grey), of control (A) and LPS samples (B). Values are means with SEM for $n=11$. $a, b$ : different letters represent significant $(P<0 \cdot 05)$ differences between time points within cell populations: PMN decreased between $0 \mathrm{~h}$ and $1 \mathrm{~h}$ in $\mathrm{A}$ and $\mathrm{B}$.

are already extenuated. Therefore, the increase of cell loss after $6 \mathrm{~h}$ post incubation most likely reflects the fact that cells are less resistant after a long presence in the milk. These findings explain the rapid decrease of the number of cells in the milk with incubation time in Experiments 2 and 3 independently of SCC and milk fraction. During the migration from blood into milk PMN utilize energy reserves needed for efficient phagocytosis and killing of invading pathogens (Newbould, 1973). In the milk, striking changes occur in the morphology of PMN owing to the ingestion of fat globules and casein (Paape et al. 1975; Paape \& Guidry, 1977) by endocytosis. From this internalization of cell membrane result intracellular membrane bound vacuoles, a loss of pseudopodia, and cell rounding (Paape et al. 2003; Rainard \& Riollet, 2006; Burvenich et al. 2007). These morphological and physiological changes consume a lot of energy which induces a decrease in phagocytic and bactericidal activity and, therefore, an impairment of the mammary gland defence (Paape et al. 2003; Rainard \& Riollet, 2006; Burvenich et al. 2007). Blood PMN have a short half-life (Carlson \& Kaneko, 1975) and they spontaneously undergo apoptosis (Fadeel et al. 1998; Smits et al. 1999). According to Paape et al. (2002) PMN function as phagocytes persists for 1-2 $\mathrm{d}$ after leaving the blood circulation. Furthermore, migration of PMN across collagencoated membranes induces an apoptotic response (Van Oostveldt et al. 2002b). In addition, milk, rich in casein and fat globules, is not an optimal culture medium (Paape et al. 2003; Burvenich et al. 2007). Comparable mechanisms are probably involved in the disappearance of leucocytes other than PMN in milk. Therefore, the cells were expected to have a short life in the removed milk and the 
Table 2. Relative mRNA expression ( \pm SEM for $n=6$ ) of immunomodulators and apoptosis factors in control and LPS-treated samples at 0, 1, 3 and $6 \mathrm{~h}$. Casp3, TLR4, and GM-CSF mRNA expression did not change within incubation time. Fas, TNF- $\alpha$, IL-8, and Lf mRNA expression was decreased after $6 \mathrm{~h}$. COX-2 expression was decreased in LPS-treated samples after $6 \mathrm{~h}$. Lz expression decreased after $3 \mathrm{~h}$

Rel. mRNA

expression

TNF- $\alpha$

IL-8

Lf

Casp3

Fas

COX-2

$\mathrm{Lz}$

GM-CSF

TLR4
Control samples

\begin{tabular}{|c|c|c|c|}
\hline $\mathrm{Oh}$ & $1 \mathrm{~h}$ & $3 \mathrm{~h}$ & $6 \mathrm{~h}$ \\
\hline $12 \cdot 51 \pm 079^{a}$ & $14 \cdot 15 \pm 0 \cdot 66^{\mathrm{a}}$ & $11 \cdot 87 \pm 1 \cdot 25^{\mathrm{a}}$ & $9 \cdot 61 \pm 0 \cdot 92^{b}$ \\
\hline $14 \cdot 06 \pm 1 \cdot 06^{\mathrm{ab}}$ & $15 \cdot 23 \pm 0 \cdot 85^{\mathrm{a}}$ & $13 \cdot 60 \pm 1 \cdot 41^{\mathrm{a}}$ & $11 \cdot 86 \pm 1 \cdot 48^{b}$ \\
\hline $8 \cdot 19 \pm 0 \cdot 62^{a b}$ & $8 \cdot 71 \pm 0 \cdot 38^{\mathrm{a}}$ & $7 \cdot 70 \pm 0 \cdot 65^{\mathrm{a}}$ & $5 \cdot 88 \pm 0 \cdot 69^{b}$ \\
\hline $11 \cdot 09 \pm 0 \cdot 47^{\mathrm{a}}$ & $10 \cdot 69 \pm 0 \cdot 27^{a}$ & $11 \cdot 22 \pm 0 \cdot 36^{a}$ & $11 \cdot 49 \pm 0 \cdot 26^{\mathrm{a}}$ \\
\hline $7 \cdot 23 \pm 0 \cdot 69^{a}$ & $8.03 \pm 0.62^{\mathrm{a}}$ & $6 \cdot 35 \pm 1 \cdot 25^{\mathrm{a}}$ & $4 \cdot 18 \pm 1 \cdot 14^{b}$ \\
\hline $10 \cdot 78 \pm 1^{\mathrm{a}}$ & $12 \cdot 05 \pm 0 \cdot 90^{\mathrm{a}}$ & $10 \cdot 28 \pm 1 \cdot 62^{a}$ & $8 \cdot 34 \pm 1 \cdot 66^{\mathrm{ab}}$ \\
\hline $9 \cdot 23 \pm 1 \cdot 42^{a b}$ & $11 \cdot 13 \pm 0 \cdot 5^{\mathrm{a}}$ & $7 \cdot 72 \pm 1 \cdot 5^{b}$ & $4 \cdot 48 \pm 1 \cdot 37^{\mathrm{c}}$ \\
\hline $8 \cdot 33 \pm 1 \cdot 16^{a}$ & $9 \cdot 93 \pm 1 \cdot 12^{\mathrm{a}}$ & $9 \cdot 22 \pm 1 \cdot 68^{\mathrm{a}}$ & $8 \cdot 58 \pm 1 \cdot 36^{a}$ \\
\hline $14 \cdot 61 \pm 0 \cdot 39^{a}$ & $14 \cdot 41 \pm 0 \cdot 43^{a}$ & $14 \cdot 68 \pm 0 \cdot 37^{a}$ & $15 \cdot 08 \pm 0 \cdot 15^{a}$ \\
\hline
\end{tabular}

\begin{tabular}{cccc}
\multicolumn{4}{c}{ LPS samples } \\
\hline $0 \mathrm{~h}$ & $1 \mathrm{~h}$ & $3 \mathrm{~h}$ & $6 \mathrm{~h}$ \\
$12 \cdot 51 \pm 0 \cdot 79^{\mathrm{a}}$ & $12 \cdot 18 \pm 1 \cdot 24^{\mathrm{a}}$ & $10 \cdot 85 \pm 1 \cdot 36^{\mathrm{ac}}$ & $8 \cdot 86 \pm 0 \cdot 51^{\mathrm{bc}}$ \\
$14 \cdot 06 \pm 1 \cdot 06^{\mathrm{a}}$ & $13 \cdot 39 \pm 1 \cdot 17^{\mathrm{ac}}$ & $12 \cdot 50 \pm 1 \cdot 24^{\mathrm{a}}$ & $10 \cdot 89 \pm 1 \cdot 04^{\mathrm{bc}}$ \\
$8 \cdot 19 \pm 0 \cdot 62^{\mathrm{ac}}$ & $8 \cdot 24 \pm 0 \cdot 35^{\mathrm{a}}$ & $7 \cdot 12 \pm 0 \cdot 45^{\mathrm{ac}}$ & $6 \cdot 06 \pm 0 \cdot 6^{\mathrm{bc}}$ \\
$11 \cdot 09 \pm 0 \cdot 47^{\mathrm{a}}$ & $11 \cdot 14 \pm 0 \cdot 32^{\mathrm{a}}$ & $11 \cdot 50 \pm 0 \cdot 19^{\mathrm{a}}$ & $11 \cdot 58 \pm 0 \cdot 24^{\mathrm{a}}$ \\
$7 \cdot 23 \pm 0 \cdot 69^{\mathrm{a}}$ & $6 \cdot 81 \pm 0 \cdot 75^{\mathrm{a}}$ & $5 \cdot 53 \pm 0 \cdot 98^{\mathrm{a}}$ & $3 \cdot 01 \pm 0 \cdot 71^{\mathrm{b}}$ \\
$10 \cdot 78 \pm 1^{\mathrm{a}}$ & $10 \cdot 69 \pm 1 \cdot 2^{\mathrm{a}}$ & $9 \cdot 92 \pm 1 \cdot 59^{\mathrm{a}}$ & $7 \cdot 54 \pm 1 \cdot 66^{\mathrm{b}}$ \\
$9 \cdot 23 \pm 1 \cdot 42^{\mathrm{a}}$ & $8 \cdot 73 \pm 1 \cdot 71^{\mathrm{a}}$ & $5 \cdot 97 \pm 1 \cdot 39^{\mathrm{d}}$ & $3 \cdot 28 \pm 0 \cdot 87^{\mathrm{edc}}$ \\
$8 \cdot 33 \pm 1 \cdot 16^{\mathrm{a}}$ & $8 \cdot 21 \pm 1 \cdot 65^{\mathrm{a}}$ & $9 \cdot 03 \pm 1 \cdot 82^{\mathrm{a}}$ & $8 \cdot 16 \pm 0 \cdot 93^{\mathrm{a}}$ \\
$14 \cdot 61 \pm 0 \cdot 39^{\mathrm{a}}$ & $14 \cdot 76 \pm 0 \cdot 24^{\mathrm{a}}$ & $15 \cdot 05 \pm 0 \cdot 17^{\mathrm{a}}$ & $15 \cdot 18 \pm 0 \cdot 1^{\mathrm{a}}$
\end{tabular}

a-e: Means within a row with different superscript letters differ $(P<0 \cdot 05)$

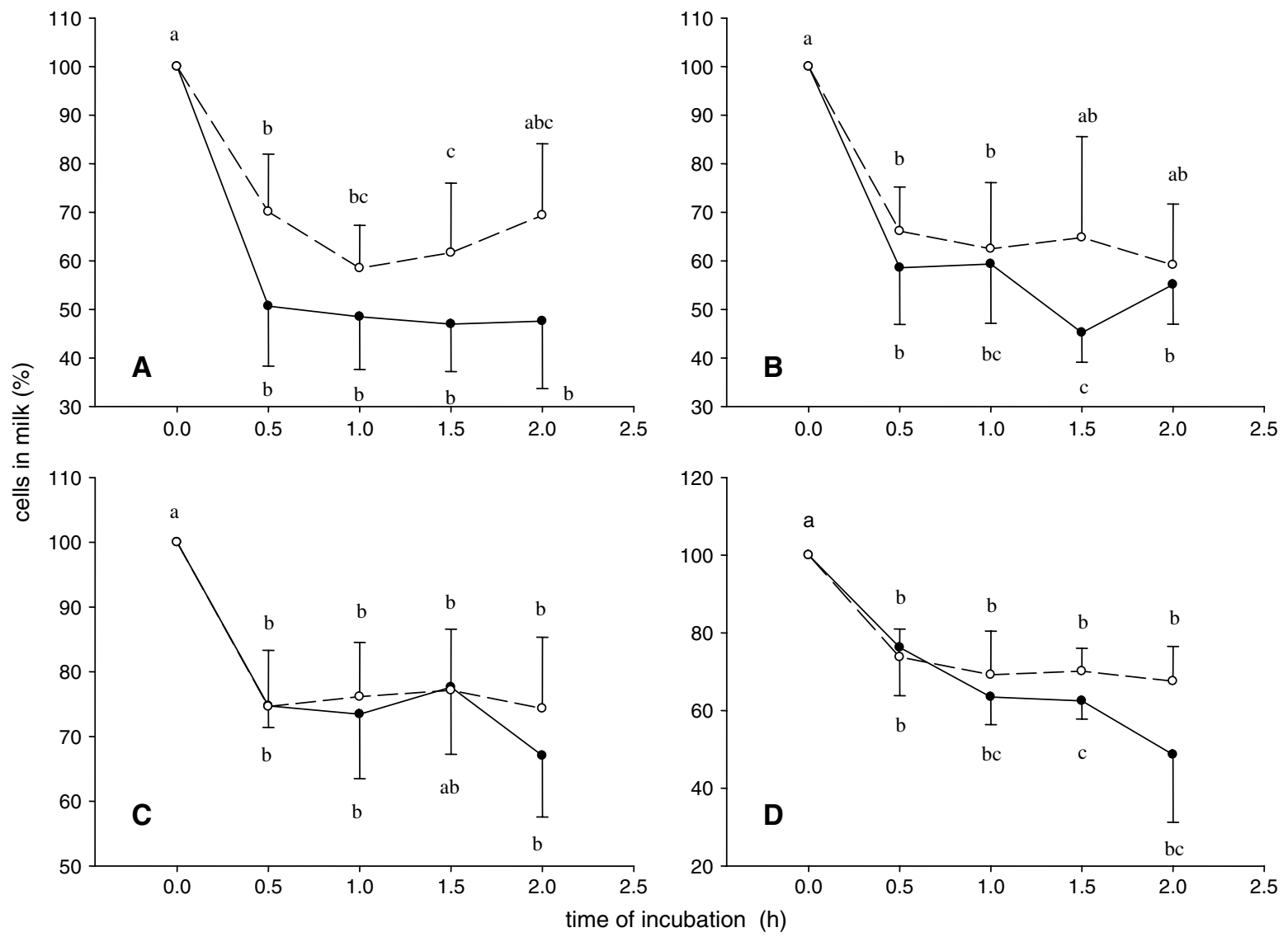

Fig. 4. Milk cell count (\%) of LQ_control (A), LQ_LPS treated (B), HQ_control (C) and HQ_LPS treated samples (D) at $0,0 \cdot 5,1,1 \cdot 5$ and $2 \mathrm{~h}$; foremilk $(\bullet)$ and alveolar milk $(\bigcirc)$. Values are means with SEM for $n=4-6 .{ }^{\mathrm{a}-\mathrm{c}}$ : means within one group without common letters tended to differ $(P<0 \cdot 1)$. Cell counts decreased within one hour of incubation with no significant differences between foremilk and alveolar milk samples and between control and LPS treatment.

rapid disappearance of leucocytes incubated in milk was not surprising.

In Experiment 2 (SCC of $60 \pm 10 \times 10^{3}$ cells $/ \mathrm{ml}$ ) LPS treatment reduced the number of cells compared with control samples. However, no differences between controls and LPS treatment could be seen in the Experiment 3 with high $\left(>200 \times 10^{3}\right)$ and low $\left(<50 \times 10^{3}\right)$ cell counts between cisternal and alveolar milk. Van Oostveldt et al. 
Table 3. Cell populations (in \%) at time $0 \mathrm{~h}$ for each group: low- (LQ) and high-SCC quarter milk (HQ), foremilk (FM) and alveolar milk (AM). Values are means with SEM for $n=6$. No significant changes were observed within the $2 \mathrm{~h}$ of the experiment

$\begin{array}{llll}\text { Groups } & \begin{array}{l}\text { Polymorphonuclear } \\ \text { neutrophils }\end{array} & \text { Macrophages } & \text { Lymphocytes } \\ \text { LQ_FM } & 47 \cdot 3 \pm 12 \cdot 0 & 50 \cdot 1 \pm 12 \cdot 5 & 2 \cdot 6 \pm 1 \cdot 2 \\ \text { LQ_AM } & 44 \cdot 6 \pm 11 \cdot 6 & 51 \cdot 4 \pm 11 \cdot 7 & 4 \cdot 3 \pm 2 \cdot 0 \\ \text { HQ_FM } & 43 \cdot 8 \pm 14 \cdot 5 & 54 \cdot 8 \pm 14 \cdot 1 & 1 \cdot 6 \pm 1 \cdot 1 \\ \text { HQ_AM } & 53 \cdot 6 \pm 11 \cdot 4 & 45 \cdot 9 \pm 11 \cdot 1 & 0 \cdot 6 \pm 0 \cdot 5\end{array}$

(2002a) showed that apoptosis of blood PMN after an intramammary challenge with Esch. coli was accelerated. On the other hand, LPS stimulation of blood leucocytes in vitro caused spontaneous inhibition of PMN apoptosis (Mangan et al. 1991; Colotta et al. 1992; Hachiya et al. 1995). In addition, after LPS intramammary challenge, programmed cell death of milk PMN is decreased (Ryśanek et al. 2005). It remains unclear why LPS had different influences on the cells in the different experiments of this study.

In the present study the viability of the cells differed widely in all experiments. However, in all experiments the viability was stable within the first $3 \mathrm{~h}$ of incubation. Nevertheless, the viability (Mehrzad et al. 2001b, 2004) of cells in our study was lower than in other studies where the viability was above $88 \%$ (Sarikaya et al. 2005) and was still $88 \%$ after $8 \mathrm{~h}$ incubation at $37{ }^{\circ} \mathrm{C}$ (Prgomet et al. 2005). It is most likely that in these studies dead cells were already cracked and washed away by centrifugation and washing steps according to Experiment 1. Previous studies compared cells from different milk fractions and described an increase in SCC and in cell viability from FM to AM (Sarikaya et al. 2005). Surprisingly, in our investigation, the variation of cell viability between both fractions did not follow a definite pattern and differed in each quarter. The relatively high proportion of PMN can indicate a previous or incipient inflammation (Persson-Waller, 2000; Jacobsen et al. 2005) and the infection status has an influence on PMN viability (Mehrzad et al. 2001a). However, at the time point of sampling the SCC of the sampled quarter was low with no signs of detectable inflammation. This shows that the definition of the milk samples through only the SCC is not sufficient and other parameters such as previous infections, lactation stage (Mehrzad et al. 2001b), milk composition, and surely other parameters like the lactation number (Mehrzad et al. 2002) have to be considered to explain the differences in cell populations.

The differential cell count with the microscope was performed by one examiner, because there is a subjective influence (Schröder \& Hamann, 2005). The distribution of cell populations at $0 \mathrm{~h}$ showed a difference in Experiments 2 and 3. In Experiment 2 (mean SCC of $60 \pm 10 \times 10^{3}$ cells/ $\mathrm{ml}) \mathrm{PMN}$ represented the biggest fraction of somatic cells. In Experiment 3 [FM and AM fractions, low $\left(<50 \times 10^{3}\right.$ cells $/ \mathrm{ml})$ and high $\left(>200 \times 10^{3}\right.$ cells $\left./ \mathrm{ml}\right)$ SCC] the distribution of cells was almost 50\% PMN and 50\% M $\phi$ in all groups. Sarikaya et al. (2006) showed the proportion of $M \phi$ to be the highest in milk with a SCC of $(12-100) \times 10^{3}$ cells/ml, almost equal with PMN in milk with a SCC of $(100-350) \times 10^{3}$ cells $/ \mathrm{ml}$, and the proportion of PMN the highest in milk with a SCC $>350 \times 10^{3}$ cells $/ \mathrm{ml}$. On the other hand, Olde Riekerink et al. (2007) found $M \phi$ to be always the predominant fraction of milk cells independently of the SCC. The reason for the differences in our study is, again, most likely due to the definition of the milk samples through only the SCC.

LPS stimulation increases mRNA expression of immunomodulators in mammary tissue (Schmitz et al. 2004). In milk cells Prgomet et al. (2005) found increased mRNA expression of TNF- $\alpha$, IL- 6 , and IL- $1 \beta$ in response to LPS with a peak after 1-3 $\mathrm{h}$ wherein the cells were incubated in RPMI 1640 medium, supplemented with 10\% inactivated FCS. The decrease of mRNA expression of immune factors and of TLR4 that recognizes LPS (Werling et al. 2006) in cells incubated in milk is rather a lack of the ability to respond to this stimulation than a regulated mechanism. It shows the degenerative changes of the cells. It reflects a reduced immune competence and confirms that milk is not a good environment to maintain the efficiency and the viability of the cells (Paape et al. 2003; Burvenich et al. 2007).

In freshly removed milk, Pfaffl et al. (2003) showed that Lf and COX-2 mRNA expression was higher in cells from high SCC quarters $\left(>150 \times 10^{3}\right.$ cells $\left./ \mathrm{ml}\right)$ than in cells from low SCC quarters. If we assume that a high SCC is due to pathogen stimulation, we can compare these results of high SCC with our results of LPS stimulation. In addition, Lee et al. (2006) showed that after intramammary challenge with Esch. coli mRNA expression of TNF- $\alpha$ was elevated at $8 \mathrm{~h}$ after infection and the mRNA expression of IL-8 was elevated at $16 \mathrm{~h}$ and $24 \mathrm{~h}$ after infection. However, the discrepancy with our experiments may be explained by the ex-vivo conditions. It shows that cells newly recruited into the mammary gland after pathogen contact are most likely responsible for an increased expression of immunomodulators in the milk and not the cells that are already resident. Furthermore, under ex-vivo conditions, resident cells have no contact and, therefore, no possible interaction with mammary tissue. Eukaryotic cells generally die either by necrosis or by apoptosis (Duvall \& Willie, 1986). Both forms of extinction exist in the cavity system of the juvenile bovine mammary gland to eliminate PMN (Sládek \& Ryšánek, 2000). Didier \& Bruckmaier (2004) found an increased mRNA expression of the apoptosis factor Fas in mammary tissue after LPS challenge, but could not detect a change of the mRNA expression of these factors in somatic milk cells. These results show that the milk cells do not respond to LPS challenge with an increased mRNA expression of apoptosis factors and that accords with our ex-vivo study where no changes in Fas or Casp3 mRNA expression in cells incubated in milk and stimulated with 
LPS could be observed. Milk cells seem to undergo necrosis some hours after the diapedesis from blood into the milk. The cells, obviously, do not undergo apoptosis but necrosis, which explains the decrease in cell count after $3 \mathrm{~h}$ of incubation, the loss of cells after centrifugation, and also the percentage of viable cells in relation to intact cells.

In conclusion, this study showed that that resident milk cells were less viable, less able to respond to immunological stimulation, and less immune competent than freshly migrated cells from blood into the milk. Therefore, cells that are already in milk are less important for a good immune competence, and the best protection of the mammary gland against infection is a fast recruitment of new immune cells from the blood which is indicated by a rapid increase of the SCC after pathogen invasion.

This study was supported by the $\mathrm{H}$ Wilhelm SchaumannStiftung, Hamburg, Germany. We are grateful to C Morel and C Philipona for their excellent technical assistance.

\section{References}

Bannerman DD, Paape MJ, Lee JW, Zhao X, Hope JP \& Rainard C 2004 Escherichia coli and Staphylococcus aureus elicit differential innate immune responses following intramammary infection. Clinical and Diagnostic Laboratory Immunology 11 463-472

Boudjellab N, Chan-Tang HS, Li HS \& Zhao X 1998 Interleukin 8 response by bovine mammary epithelial cells to lipopolysaccharide stimulation. American Journal of Veterinary Research 59 1563-1567

Brolund L 1985 Cell counts in bovine milk. Causes of variation and applicability for diagnosis of subclinical mastitis. Acta Veterinaria Scandinavica Supplementum 80 1-123

Bruckmaier RM \& Blum JW 1996 Simultaneous recording of oxytocin release, milk ejection and milk flow during milking of dairy cows with and without prestimulation. Journal of Dairy Research 63 201-208

Burvenich C, Paape MJ, Hill AW, Guidry AJ, Miller RH, Heyneman $R$, Kremer WD \& Brand A 1994 Role of the neutrophil leucocyte in the local and systemic reactions during experimentally induced $E$. coli mastitis in cows immediately after calving. Veterinary Quarterly $\mathbf{1 6}$ $45-50$

Burvenich C, Bannerman DD, Lippolis JD, Peelman L, Nonnecke BJ, Kehrli ME Jr \& Paape MJ 2007 Cumulative physiological events influence the inflammatory response of the bovine udder to Escherichia coli infections during the transition period. Journal of Dairy Science $\mathbf{9 0}$ Suppl $139-54$

Carlson GP \& Kaneko JJ 1975 Intravascular granulocyte kinetics in developing calves. American Journal of Veterinary Research 36 421-425

Colotta F, Re F, Polentarutti N, Sozzani S \& Mantovani A 1992 Modulation of granulocyte survival and programmed cell death by cytokines and bacterial products. Blood 80 2012-2020

Didier A \& Bruckmaier RM 2004 mRNA expression of apoptosis-related genes in mammary tissue and milk cells in response to lipopolysaccharide challenge and during subclinical mastitis. Milchwissenschaft 59 119-123

Duvall E \& Willie AH 1986 Death and the cell. Immunology Today 7 $115-119$

Fadeel B, Ahlin A, Henter JI, Orrenius S \& Hampton MB 1998 Involvement of caspases in neutrophil apoptosis: regulation by reactive oxygen species. Blood 92 4808-4818

Hachiya O, Takeda Y, Miyata H, Watanabe H, Yamashita T \& Sendo F 1995 Inhibition by bacterial lipopolysaccharide of spontaneous and
TNF-alpha-induced human neutrophil apoptosis in vitro. Microbiology and Immunology 39 715-723

Harmon RJ \& Heald CW 1982 Migration of polymorphonuclear leukocytes into the bovine mammary gland during experimentally induced Staphylococcus aureus mastitis. American Journal of Veterinary Research 43 992-998

Harmon RJ 1994 Physiology of mastitis and factors affecting somatic cell counts. Journal of Dairy Science 77 2103-2112

Jacobsen S, Toelboell T \& Andersen PH 2005 Dose dependency and individual variability in selected clinical, haematological and blood biochemical responses after systemic lipopolysaccharide challenge in cattle. Veterinary Research 36 167-178

Kehrli EM \& Shuster DE 1994 Factors affecting milk somatic cells and their role in health of the bovine mammary gland. Journal of Dairy Science 77 619-627

Lee JW, Bannerman DD, Paape MJ, Huang MK \& Zhao X 2006 Characterization of cytokine expression in milk somatic cells during intramammary infections with Escherichia coli or Staphylococcus aureus by real-time PCR. Veterinary Research 37 219-229

Mangan DF, Welch GR \& Wahl SM 1991 Lipopolysaccharide, tumor necrosis factor-alpha, and IL-1 beta prevent programmed cell death (apoptosis) in human peripheral blood monocytes. Journal of Immunology 146 1541-1546

Mehrzad J, Dosogne H, Meyer E \& Burvenich C 2001a Local and systemic effects of endotoxin mastitis on the chemiluminescence of milk and blood neutrophils in dairy cows. Veterinary Research 32 131-144

Mehrzad J, Duchateau L \& Burvenich C 2004 Viability of milk neutrophils and severity of bovine coliform mastitis. Journal of Dairy Science $\mathbf{8 7}$ 4150-4162

Mehrzad J, Dosogne H, Meyer E, Heyneman R \& Burvenich C 2001b Respiratory burst activity of blood and milk neutrophils in dairy cows during different stages of lactation. Journal of Dairy Research $\mathbf{6 8}$ 399-415

Mehrzad J, Duchateau L, Pyörälä S \& Burvenich C 2002 Blood and milk neutrophil chemiluminescence and viability in primiparous and pluriparous dairy cows during late pregnancy, around parturition and early lactation. Journal of Dairy Science 85 3268-3276

Menaker RJ \& Jones NL 2003 Fascination with bacteria-triggered cell death: the significance of Fas-mediated apoptosis during bacterial infection in vivo. Microbes and Infection 5 1149-1158

Newbould FH 1973 The effect of added serum and glucose, and some inherent factors, on phagocytosis in vitro by milk leukocytes from several cows. Canadian Journal of Comparative Medicine 37 189-194

Olde Riekerink RG, Barkema HW, Veenstra W, Berg FE, Stryhn H \& Zadoks RN 2007 Somatic cell count during and between milkings. Journal of Dairy Science 90 3733-3741

Paape MJ, Guidry AJ, Kirk ST \& Bolt DJ 1975 Measurement of phagocytosis of 32P-labeled Staphylococcus aureus by bovine leukocytes: lysostaphin digestion and inhibitory effect of cream. American Journal of Veterinary Research 36 1737-1743

Paape MJ \& Guidry AJ 1977 Effect of fat and casein on intracellular killing of Staphylococcus aureus by milk leukocytes. Proceeding of the Society for Experimental Biology and Medicine 155 588-593

Paape M, Mehrzad J, Zhao X, Detilleux J \& Burvenich C 2002 Defence of the bovine mammary gland by polymorphonuclear neutrophil leukocytes. Journal of Mammary Gland Biology and Neoplasia 7 109-121

Paape MJ, Bannerman DD, Zhao X \& Lee JW 2003 The bovine neutrophil: Structure and function in blood and milk. Veterinary Research 34 597-627

Persson-Waller K 2000 Mammary gland immunology around parturition. Influence of stress, nutrition and genetics. Advances in Experimental Medicine and Biology 480 231-245

Pfaffl MW, Wittmann SL, Meyer HH \& Bruckmaier RM 2003 Gene expression of immunologically important factors in blood cells, milk cells and mammary tissue of cows. Journal of Dairy Science $\mathbf{8 6}$ 538-545

Prgomet C, Sarikaya H, Bruckmaier RM \& Pfaffl MW 2005 Short-term effects on pro- inflammatory cytokine, Lactoferrin and CD14 mRNA 
expression levels in bovine immunoseparated milk and blood cells treated by LPS. Journal of Veterinary Medicine A, Physiology, Pathology, Clinical Medicine A52 317-324

Rainard P \& Riollet C 2006 Innate immunity of the bovine mammary gland. Veterinary Research 37 369-400

Rysánek D, Sládek Z, Vasícková D \& Faldyna M 2005 Effects of certain inducers of leukocytes migration into the bovine mammary gland on neutrophil apoptosis manifestation in a subsequent in vitro cultivation. Physiological Research 54 305-312

Robertson JD, Orrenius S \& Zhivotovsky B 2000 Review: nuclear events in apoptosis. Journal of Structural Biology 129 246-358

Sarikaya H, Prgomet C, Pfaffl MW \& Bruckmaier RM 2004 Differentiation of leukocytes in bovine milk. Milchwissenschaft 59 586-589

Sarikaya H, Werner-Misof C, Atzkern M \& Bruckmaier RM 2005 Distribution of leucocyte populations, and milk composition, in milk fractions of healthy quarters in dairy cows. Journal of Dairy Research 72 486-492

Sarikaya H, Schlamberger G, Meyer HH \& Bruckmaier RM 2006 Leukocyte populations and mRNA expression of inflammatory factors in quarter milk fractions at different somatic cell score levels in dairy cows. Journal of Dairy Science 89 2479-2486

Schmitz S, Pfaffl MW, Meyer HH \& Bruckmaier RM 2004 Short-term changes of mRNA expression of various inflammatory factors and milk proteins in mammary tissue during LPS-induced mastitis. Domestic Animal Endocrinology 26 111-126

Schröder AC \& Hamann J 2005 The influence of technical factors on differential cell count in milk. Journal of Dairy Research $\mathbf{7 2}$ 153-158

Sládek Z \& Ryšánek D 1999 Ultrastructure of phagocytes from mammary glands of non-pregnant heifers. Anatomia Histologia Embryologia 28 291-297
Sládek Z \& Ryšánek D 2000 Apoptosis of polymorphonuclear leukocytes of the juvenile bovine mammary gland during induced influx. Veterinary Research 31 553-563

Smits E, Burvenich C, Guidry AJ, Heyneman R \& Massart-Leen A 1999 Diapedesis across mammary epithelium reduces phagocytic and oxidative burst of bovine neutrophils. Veterinary Immunology and Immunopathology 68 169-176

Sordillo LM \& Streicher KL 2002 Mammary gland immunity and mastitis susceptibility. Journal of Mammary Gland Biology and Neoplasia 7 135-146

Suriyasathaporn W, Schukken YH, Nielen M \& Brand A 2000 Low somatic cell count: a risk factor for subsequent clinical mastitis in a dairy herd. Journal of Dairy Science $\mathbf{8 3}$ 1248-1255

Takeuchi O, Hoshino K, Kawai T, Sanjo H, Takada H, Ogawa T, Takeda K \& Akira S 1999 Differential roles of TLR2 and TLR4 in recognition of gram-negative and gram-positive bacterial cell wall components. Immunity 11 443-451

Van Oostveldt K, Tomita GM, Paape MJ, Capuco AV \& Burvenich C 2002a Apoptosis of bovine neutrophils during mastitis experimentally induced with Escherichia coli or endotoxin. American Journal of Veterinary Research 63 448-453

Van Oostveldt K, Paape MJ \& Burvenich C 2002b Apoptosis of bovine neutrophils following diapedesis through a monolayer of endothelial and mammary epithelial cells. Journal of Dairy Science 85 139-147

Wellnitz O \& Kerr DE 2004 Cryopreserved bovine mammary cells to mode epithelial response to infection. Veterinary Immunology and Immunopathology 101 191-202

Werling D, Piercy J \& Coffey TJ 2006 Expression of TOLL-like receptor (TLR) by bovine antigen-presenting cells - Potential role in pathogen discrimination? Veterinary Immunology and Immunopathology 112 $2-11$ 